X. Crowe, F. W.. and Schull, W. J.: Diagnostic importance of cafe-au-lait spots in neurofibromatosis. Arch. Intern. Med.. 91: 758 (1953).

9. Davis, F. A.: Primary tumors of the optic nerve (a phenomenon of Recklinghausen's disease). A clinical and pathologic study with a report of five cases and a review of the literature. Arch. Ophthalmol.. 23: 735, 957 (1940).

10. Delleman, J. W., DeJong. J. G. Y., and Blecker. G. M.: Meningiomas in five members of a family over two generations, in one member simultaneously with acoustic neuromas. Neurology, 28: 567 (1978).

1I. Fowler, F. D., and Matson. D. D.: Gliomas of the optic pathway in childhood J. Neurosurg., 14: 515 (1957).

12. Greene. J. F.. Fitzwater. J. E.. and Burgess, J.: Arterial lesions associated with neurofibromatosis. Am. J. Clin. Pathol., 82: 481 (1974).

13. Holt, J. F.: Neurofibromatosis in children. Am. J. Roentgenol.. 1.30: 615 (1978)

14. Holt. J. F.. and Kuhns, L. R.: Macrocranium and macrocephaly in neurofibromatosis. Skel. Radiol., I: 24 (1976).

15. Holt, J. F., and Wright. E. M.: The radiologic features of neurofibromatosis. Radiology, 51: 647 (1948).

16. Klatte. E. C.. Franken, E. A., and Smith, J. A.: The radiographic spectrum in neurofibromatosis. Semin. Roentgenol.. 11: 17 (1976).

17. Kramer, W.: Lesions of the central nervous system in multiple neurofibromatosis Psychiatr. Neurol. Neurochir., 74: 349 (1971).

18. Lucky, A. W.. Mahoney, M. J.. Barnett, R. J., and Rosenberg. L. E.: Electron microscopy of human skin tibroblasts in situ during growth in culture. Exp. (cell Res., 92: 383 (1975).

19. McKeen. E. A., Bodurtha, J.. Meadows, A. T., Douglass, E. C., and Mulvihill, J. J.: Rhabdomyosarcoma complicating multiple neurofibromatosis. J. Pediatr. 9.3: 992 (1978).

20. McKusick, V. A.: Mendelian Inheritance in Man. (The Johns Hopkins University Press, Baltimore. MD, 1975)

21. Meadows, A. T., D'Angio, G. J.. Mike. V., Banfi. A., Harris, C.. Jenkins, R. D T., and Schwarty. A.: Patterns of second malignant neoplasms in children. Cancer (Phila.). 41): 1903 (1977)

22. Reich, S. E., and Wiernik. P. H.: Von Recklinghausen's neurofibromatosis and acute leukemia. Am. J. Dis. (hild., 130: 888 (1976).
23. Reubi, F.: Les vaisseux et les glandes endocrines dans la neurofibromatose. Le syndrome synpathicotonique dans la maladie de Recklinghausen. Schweiz. $Z$. Pathol. Bakteriol.. 7: 168 (1944).

24. Richlin, P. R. Kranik, A. Van Herpe, L., and Suffecod, S. L: C'ongenital pseudoarthrosis of both bones of the forearm. A case report. J. Bone J. Surg. Am., 58: 1032 (1976)

25. Roloff, J. S.. Najjar, J. L., and Lukens, J. N.: Erythroleukemia in an infant with neurofibromatosis. J. Pediatr., 92: 888 \{1976).

26. Salerno, N. R., and Edeiken, J.: Vertebral scalloping in neurofibromatosis Radiology, 97: 509 (1970)

27. Tilford. D. L.. and Heyn. R. M.: Neurofibromatosis and xantholeukemia. J Pediatr., 9.3: 319 (1978)

28. Treves, F.: Congenital deformity. Br. Med. J., 2: 1140$)(1884)$

29. Vinken, P. J., and Bruyn. (i. W.. eds.: Handbook of ('linical Neurology. Vol. 14. The Phakomatoses. (American Elsevier Publishing (o.. Inc.. New York, 1972).

30. Young, D. F.. Eldridge, R.. Nager, G. T.. Deland. F. H. and McNew. J. Hereditary bilateral acoustic neuroma (central neurofibromatosis). Birth Defects, 7: 73 (1971)

31. Both EGF and [ $\left.{ }^{3} \mathrm{H}\right]$ thymidine were gifts from Dr. B. G. W. Arnason. Department of Neurology. University of Chicago Hospitals and Clinics.

32. Presented in part at the meeting of the American Academy of Neurology Chicago, IL. April, 1979.

33. The authors thank Dr. Anne Lucky. Department of Dermatology. Yale Medical School, for her review of the manuscript.

34. The authors wish to acknowledge the patient retyping of this manuscript by (iregory (ietschman and Gerald Birnbaum.

35. Requests for reprints should be addressed to: Marvin Zelkowitz. M.D. Division of Pediatric Neurology. The University of (hicago. 950) E. 59th St.. Box 228 ('hicago, IL 60637 (U.S.A.).

36. This research was supported by The Home for Destitute and Crippled Children. Chicago, Illinois. The Easter Seals Research Foundation, and PHS (irant So? RR-05367.

37. Received for publication January 29. 1980

38. Accepted for publication May 20, 1980.

\title{
LABORATORY DESIGN SEMINAR
}

The First Southeastern Regional Laboratory Design Seminar will be held in Atlanta, Georgia, Marrch 25-27, 1981

This Seminar will cover the planning process, laboratory ventilation, energy conservation, utility requirements, laboratory furniture selection. bichazard and carcinogen control, building technology, and design innovations that can provide maximum, adaptability and optimum performance. Laboratory tours will be available.

Further information and registration forms can be obtained from Norman V. Steere \& Associates, Inc., 140 Melbourne Ave., S.E., Minneapolis. Minnesota 55414. Phone: 612-378-2711.

Registration fee is $\$ 400$ which includes course material and luncheons.

\section{ANNOUNCEMENT}

The annual meeting of the American Society of Pediatric Nephrology will be held at the Hilton Hotel in San Francisco, California, on Tuesday evening. April 28, 1981. This year the symposium will be entitled, "State of the Nephron: The Pediatric Nephrologist View." For further information, please contact Dr. Russell Chesney, Secretary-Treasurer, American Society of Pediatric Nephrology, University of Wisconsin Clinical Sciences Center, 600 Highland Avenue, H4/452, Madison, Wisconsin 53792 